Syntax Literate: Jurnal Ilmiah Indonesia p-ISSN: 2541-0849

e-ISSN: 2548-1398

Vol. 7, No. 1, Januari 2022

\title{
APLIKASI PORTAL KONTEN WEB BERBASIS ANDROID MOBILE UNTUK MENINGKATKAN EFEKTIFITAS DOSEN DALAM TRIDHARMA
}

\section{Nurohim, Wildani Eko Nugroho}

Politeknik Harapan Bersama Tegal Jawa Tengah, Indonesia

Email: nurohim77@gmail.com, wild4n1@gmail.com

\begin{abstract}
Abstrak
Perguruan tinggi dianggap baik jika mampu memberikan hasil yang baik pula terhadap Tridharma, oleh karena itu dibutuhkan kinerja yang baik dalam pencapaiannya. Namun kenyataanya dari sekian banyak dosen tidak semua dosen mengetahui dan hafal semua link-link web baik yang dikeluarkan oleh ristek dikti maupun dari yang lain yang sama-sama penting untuk menunjang kegiatan penelitian, dan setelah kami lakukan studi observasi dilapangan dan melakukan sesi tanya jawab tentang alamat web penting yang menunjang peran dosen dalam melaksanakan Tridharma perguruan tinggi sepeti Ristek Dikti, kopertis, sinta 2, Simlitabmas, sister, arjuna, e-journal JPIT D4 TI, e-journal d3 teknik Computer SmartCom, web politehnik harapan bersama, e-journal parapemikir d3 farmasi, web d3 teknik komputer, Rejafa, dan lainya. Dari sekian banyak web tersebut diatas memang kebanyakan dosen tau namanya, tetapi ketika ditanyakan atau disuruh menuliskan link url nya kebanyakan mereka tidak dapat menuliskannya dengan baik bahkan ada yang lupa link url nya. Untuk mengatasi masalah tersebut maka diambilah tujuan dari penelitian ini adalah membuat "Aplikasi Portal Konten Web berbasis Android mobile untuk meningkatkan efektifitas Dosen dalam Tridharma". Proses Pembuatan Aplikasi dengan menggunakan Integrated Development Environment (IDE) MIT App Inventor2 (MIT-AI2) yang merupakan platform untuk memudahkan proses pembuatan aplikasi yang bertujuan untuk memudahkan para dosen dalam mengunjungi sebuah web sehingga tidak usah lagi menuliskan link Web yang akan dikunjungi tetapi hanya dengan satu kali sentuh saja sudah langsung menuju web yang akan dibuka atau dikunjungi.
\end{abstract}

Kata Kunci: URL; Portal Konten Web; MIT App Inventor2; Android Mobile

\section{Abstract}

Higher education is considered good if it is able to give good results to Tridharma, therefore good performance is needed in its efforts. But in fact, from only a few lecturers, not all lecturers know and all web links, both issued by Research and Technology, Higher Education and from others, are equally important to support research activities, and after we conducted an observation study in the field and conducted a question and answer session about addresses important websites that support the role of lecturers in implementing the Tridharma of higher education such as Research and Technology Dikti, Kopertis, Sinta 2, Simlitabmas, Sisters,

$\begin{array}{ll}\text { How to cite: } & \text { Nurohim \& Wildani eko nugroho (2022) Aplikasi Portal Konten Web Berbasis Android Mobile untuk } \\ & \text { Meningkatkan Efektifitas Dosen dalam Tridharma. Syntax Literate: Jurnal Ilmiah Indonesia, 7(1). } \\ & \text { http://dx.doi.org/10.36418/ Syntax-Literate.v7i1.1856 } \\ & 2548-1398 \\ \text { E-ISSN: } & \text { Ridwan Institute }\end{array}$


Arjuna, JPIT D4 TI e-journal, SmartCom d3 e-journal of Computer Engineering, polytechnic web of hope together, e-journal of thinkers $d 3$ pharmacy, web d3 computer engineering, Rejafa, and others. Of the many websites mentioned above, most people know the name, but when adding or writing the url link, most of them can't put it properly and some even forget the url link. To overcome this problem, the aim of this research is to create an "Android mobile-based Web Content Portal Application to increase the effectiveness of Lecturers in Tridharma". Application Development Process using the Integrated Development Environment (IDE) MIT App Inventor2 (MIT-AI2) which is a platform to facilitate the application creation process which aims to make it easier for lecturers to visit a web so that there is no need to write down a Web link to be visited but only with one just touch it directly to the web to be opened or visited.

Keywords: URL; Web Content Portal; MIT App Inventor2; Android Phone

\section{Pendahuluan}

Perkembangan Perangkat seluler yang telah menjamur pada giliranya dapat dimanfaatkan manusia sebagai media komunikasi jarak jauh yang efisian, handphone genggam misalnya lebih fleksibel dan mudah untuk dibawa kemana-mana sehingga selalu menemani pengguna dimanapun berada, perkembangan sistem operasi handphone pun telah mengalami kemajuan belum lama ini sistem operasi android telah berkembang pesat dan hampir menguasai pasar mobile (Rahayu, Merdekawati, and Zakaria 2019).

Begitu juga seiring dengan Perkembangan Kampus Politeknik Harapan Bersama Tegal yang juga tidak hanya memiliki satu website saja dan sebagai kampus yang perkembanganya sangat cepat baik dari fisik gedung, tenaga pengajar dan jumlah mahasiswa yang lebih dari 5000 mahasiswa, tak dipungkiri lagi dalam satu kampus yang memiliki 10 program setudi dimana disetiap prodi memiliki website dan E-Journal masing-masing, ditambah dengan website yang menunjang keperluan Tridharma Perguruan Tinggi seperti Simlitabmas NG2, Sinta, Sister, Kopertis VI, semuanya itu berjalan dengan platformnya masing-masing, tentunya sangat bagus jika semua webset yang ada di Kampus dan website penunjang kegiatan tridharma perguruan tinggi dijadikan dalam satu platform yang mengkafer semua website tersebut dalam satu Aplikasi Portal Konten Web Berbasis Android Mobile.

Karena banyaknya website, menyebabkan dosen tidak hafal link-link web tersebut, mereka tau namanya tapi begitu disuruh menuliskannya gak hafal dan harus lihat catatan dulu atau buka browser dulu meskipun itu bisa tapi tidak efektif.

Dari latar belakang permasalahan tersebut diatas maka sangatlah penting jika dibuat sebuah "Aplikasi portal konten web berbasis Android Mobile untuk meningkatkan efektifitas dosen dalam Tridharma" yang memudahkan para dosen dalam mengunjungi situs website yang mendukung kegiatan pengajaran, penelitian, dan pengabdian kepada masyarakat, dengan aplikasi tersebut cukup dengan klik atau sentuh logo atau gambar dari website yang akan dikunjungi maka akan langsung menuju ke url dari web tersebut. 
Tinjauan Pustaka pada Penelitian yang terkait atau sebelumnya adalah; penelitian yang dilakukan oleh Sarini Vita dewi dan edi noviar mayuska yang berjudul "Perancangan Aplikasi Portal Informasi Mahasiswa pada universitas Ubudiyah Indonesia berbasis Android" menurutnya Portal informasi pada sebuah universitas mempunyai peranan yang sangat penting bagi para mahasiswa, dosen serta staf universitas maupun yang lainnya (Dewi and Mayuska 2019).

Penelitian yang dilakukan oleh Afriandi, asrul huda, dan denny kurniadi yang berjudul Aplikasi Mobile Portal Berita Ganto.or.id berbasis android Dengan pemanfaatan teknologi perangkat bergerak (mobile device) dan perkembangan lingkungan pengembang (development environment), kita dapat merancang sebuah aplikasi mobile portal berita Ganto berbasis android. Dengan adanya aplikasi ini pengguna bisa mendapatkan informasi seputar kampus atau informasi umum pada Ganto tanpa harus membuka laptop atau terganggu dengan tampilan Ganto yang tidak user-friendly pada web browser jika diakses melalui perangkat mobile (Huda, Asrul, and Kurniadi 2015).

Penelitian yang dilakukan oleh endar suprih wihidayat dan Dwi maryono yang berjudul "Pengembangan Aplikasi Android menggunakan Integrated Development Environment (IDE) App Inventor 2" (Wihidayat and Maryono 2017).

Penelitian yang dilakukan oleh Ernawati, Asahar Johar, Sandi setiawan yang berjudul "Implementasi Metode String Matching untuk pencarian berita utama pada Portal berita Berbasis Android" setudi kasus Harian Rakyat Bengkulu" (Ernawati, Johar, and Setiawan 2019)

Penelitian yang dilakukan oleh Yosef Koko Kurniawan, Yetli Oslan, Harianto Kristanto yang berjudul "Implementasi Rest API untuk Portal Akademik UKDW berbasis Android" (Kurniawan, Oslan, and Kristanto 2013).

Penelitian yang dilakukan Fransiscus Lesomar, Hans wowor, virgina tulenan yang berjudul "Rancang Bangun Web Pariwisata Maluku Tenggara"(Lesomar, Wowor, and Tulenan 2015).

Penelitian yang berjudul "Aplikasi Web Portal manajemen Informatika Berbaasis Website dengan menggunakan framework Codeigniter dan MySql pada universitas Catur Insan Cendikia"(Ramadhan, Dewi, and Nas 2020).

Penelitian yang dilakukan oleh Muhammad Faizal, nurul arifin aristiani yang berjudul "Perancangan Portal berita daring magazinc! Sebgai media informasi mahasiswa"(Faizal and Aristarini 2020).

Penelitian yang dilakukan oleh Julianto simatupang, Erica septiani hendarti yang berjudul "Implementasi system informasi job Portal pada BPJS Ketenagakerjaan Berbasis Web" (Julianto simatupang 2021).

Penelitian yang dilakukan oleh Jefonses Yarsian Pote, Yustina Rada yang berjudul "Implementasi Portal News Citizen Journalism Dengan Konsep MVC Sebagai Media Promosi Konten Lokal Di Pulau Sumba"(Pote and Rada 2020).

Penelitian yang dilakukan oleh Selli Mariko yang berjudul "Perancangan Portal ELearning menggunakan DRUPAL CMS sebagai penunjang perkuliahan di masa 
Pandemi Covid-19"(Mariko 2020).

Kesimpulan dari penelitian sebelumnya yang dibuat adalah portal web dari sebuah web saja, sedangkan pada penelitian ini kami membuat sebuah aplikasi portal konten web yang menampung dan menampilkan link dari banyak web yang akan di kunjungi. Penelitian ini Menghasilkan Sebuah Aplikasi Portal Konten Web Berbasis Android mobile untuk meningkatkan efektifitas dosen dalam Tridharma perguruan tinggi dan mempermudah Dosen dalam mencari Informasi terkait dengan Penelitian dan pengabdian masyarakat pada link atau website yang sudah didesain sedemikian rupa sesuai dengan yang dibutuhkan.

Kebaruan atau pembeda dari penelitian ini dengan peneliti sebelumnya adalah kalo di peneliti sebelumnya hanya mengkhususkan pada satu portal web tertentu saja, sedangkan pada penelitian ini menghasilkan sebuah Aplikasi Portal Konten web berbasis Android yang didalamnya berisi konten-konten dari banyak portal website, yang penggunaannya cukup mudah hanya dengan satu kali sentuh saja logo / icon dari website yang akan dikunjungi.

\section{Metode Penelitian}

Alur dalam rencana Penelitian ini menggunakan metode SDLC (System Development Life Cycle) dalam membuat Aplikasi Portal Konten Web Berbasis Android. Berikut ini merupakan penjelasan dari tahapan-tahapan pada SDLC (shores 2012) dalam (Martias 2018).

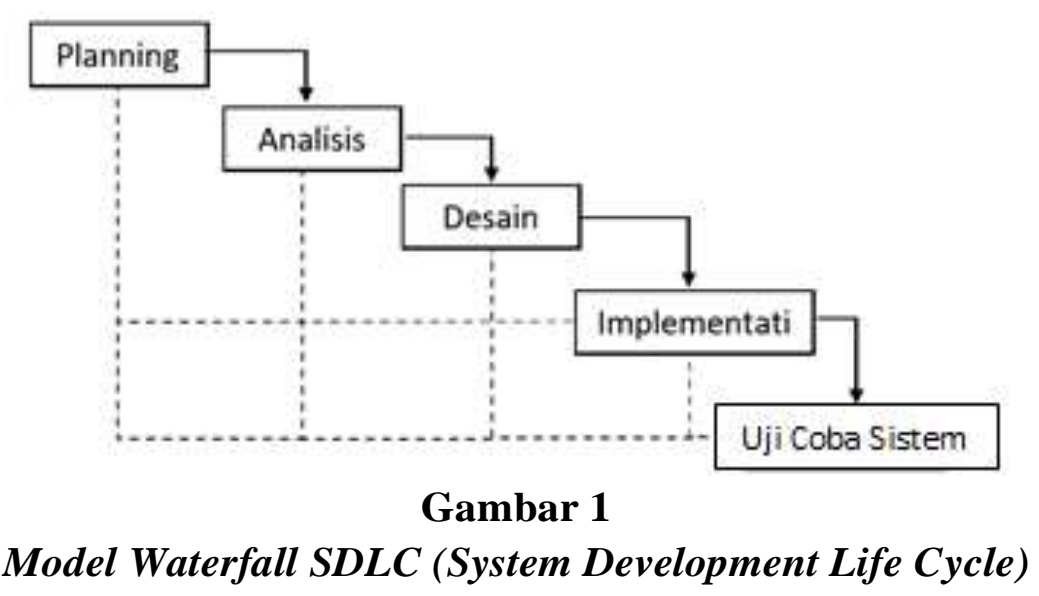

1. Planning (Perencanaan)

Tahap ini adalah tahap penentuan hal-hal penting sebagai dasar dari permasalahan yang akan dianalisis. Dalam tahap ini dilakukan identifikasi masalah, pengumpulan data, menentukan kebutuhan sistem, mengevaluasi berbagai solusi alternatif dan melakukan verifikasi data. Data-data yang dibutuhkan diperoleh dari masing-masing para Ka. Prodi, Ka. Unit, dan dari dosen. Data yang diperoleh berupa nama Link Webset dari masing-masing

Program Studi, nama Webset dari Webset Masing-masing dari Ka. Unit. 
Kemudian mempersiapkan komputer sebagai alat utama yang didalamnya sudah terinstal aplikasi yang dibutuhkan dalam membangun sebuah Aplikasi Portal Web Politeknik Harapan Bersama Tegal Berbasis Android Mobile seperti Integrated Development Environment (IDE) MIT App Inventor2 (MIT-AI2), Photoshop, dan beberapa aplikasi pendukung.

2. Analysis (analisis)

Pada tahap ini ditentukan model data yang akan digunakan dan model proses yang akan diterapkan. Pada tahap ini juga nantinya akan ditelaah lebih lanjut aspek-aspek keuntungan, tantangan dan peluang dalam menerapkan Aplikasi Portal Konten Web Berbasis Android Mobile di Politeknik Harapan Bersama Tegal.

3. Design(Desain)

Tahap ini merupakan suatu proses menginventarisir dan mengubah kebutuhan-kebutuhan menjadi bentuk karakteristik yang dimengerti oleh perangkat lunak sebelum pembuatan Aplikasi Portal Konten Web Politeknik Harapan Bersama Tegal Berbasis Android Mobile. Desain ini akan dijadikan sebuah parameter dalam pembuatan Aplikasi Portal Konten Web di Politeknik Harapan Bersama Tegal Berbasis Android Mobile, dengan mempertimbangkan faktor kemudahan pengguna, antar muka yang menarik dan ringan untuk proses instalasinya.

4. Implementation (Implementasi)

Pada tahap implementasi kegiatan yang dilakukan adalah dengan menulis pengetahuan yang telah direpresentasikan (disandikan) dengan bahasa Aplikasi Portal Konten Web Berbasis Android Mobile Untuk Meningkatkan Efektifitas Dosen Dalam Tridharma Perguruan Tinggi pemrograman Android, instalasi, demonstrasi dan penerapan sistem, orientasi pemakai, keamanan, dokumentasi dan integrasi yang kesemuanya nanti melalui proses uji coba.

5. Testing (Uji Coba)

Setelah tahapan implementasi selesai dikerjakan, tahap selanjutnya adalah dengan melakukan pengujian hasil implementasi, yaitu dengan melakukan pengujian terhadap Aplikasi Portal Konten Web Politeknik Harapan Bersama Tegal Berbasis Android Mobile dengan cara mengoperasikan diperangakat HP yang sudah terinstal aplikasinya.

Penelitian yang akan dilakukan sesuai dengan tujuan yang diinginkan, yaitu dari proses pengumpulan data baik data text, maupun data gambar dari 10 prodi yang ada di politeknik harapan beersama Tegal, dari hasil Observasi sehingga mendapatkan variable data yang dibutuhkan dan kemudian diolah menjadi sebuah Produk software Program Aplikasi Konten Web Berbasis Android Mobile yang diharapkan dengan aplikasi tersebut dapat meningkatkan Efektifitas dosen dalam kegiatan baik Pembelajaran maupun Teridaharma Perguruan Tinggi.

Model yang digunakan pada penelitian ini adalah dengan membuat Program 
Aplikasi Konten Web Berbasis Android Mobile dengan menggunakan Tools Integrated Development Environment (IDE) MIT App Inventor 2 (AI2) dalam membangun Aplikasi tersebut untuk dapat meningkatkan efektifitas dosen dalam Tri Dharma Perguruan Tinggi. MIT App Inventor merupakan Platform untuk memudahkan proses pembuatan aplikasi sederhana tanpa harus mempelajari atau menggunakan bahasa pemrograman yang terlalu banyak. (Antares 2021)

Kemudian untuk keperluan Disain user interface, Splash Screen, Logo, dan atribut lainya dari masing-masing konten web, isi dari menu tentang dan menu bantuan dengan menggunakan tools Adobe Potoshop Fungsi utama dari Adobe Photoshop hanyalah sebagai aplikasi pengedit foto atau gambar yang bertipe raster atau bitmap (Ardilas.com 2020).

\section{Hasil dan Pembahasan}

\section{A. Disain dan perancangan SplashScreen}

1. Perancangan Logo/Icon untuk tampilan Logo Aplikasi Portal Konten Web Berbasis Android Setelah anda menginstal aplikasi maka akan muncul logo

aplikasi seperti ini

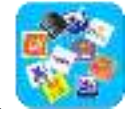

dan setelah anda klik logo tersebut maka akan muncul Splash Screen selama 5 detik seperti pada Gambar 2 dibawah ini .

2. Perancangan/Desain SplashScreen dan Blok kode untuk user Interface spashScreen

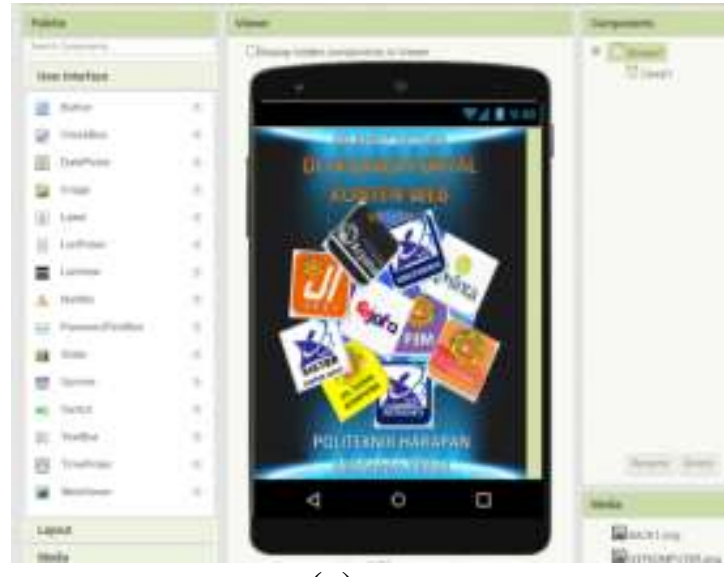

(a)

\section{Gambar 2}

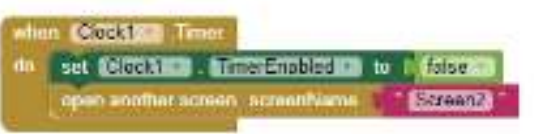

(b)

(a) Disain Splashscreen, (b) Blok Kode Untuk Disain Splashscreen

Aplikasi Portal Konten Web Berbasis Android Mobile Untuk Meningkatkan Efektifitas Dosen Dalam Tri Dharma Perguruan Tinggi. 
3. Perancangan/Desin dan Blok kode untuk user Interface Menu utama

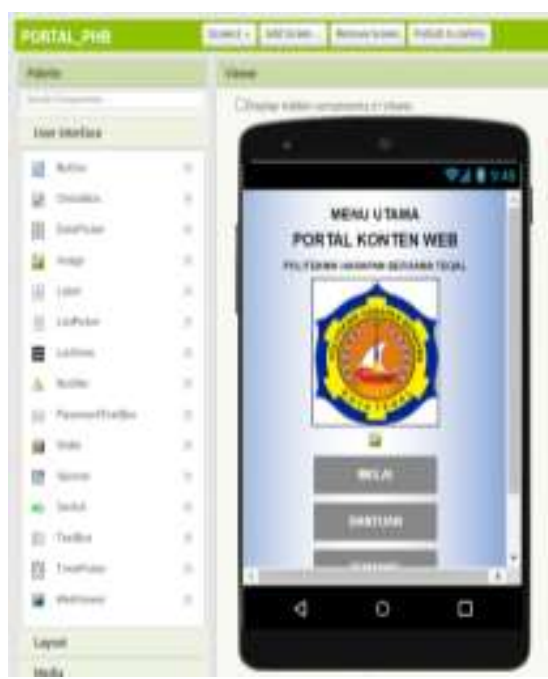

(a)

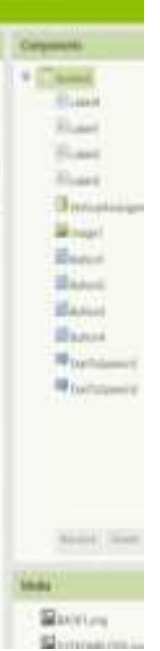

Gambar 3

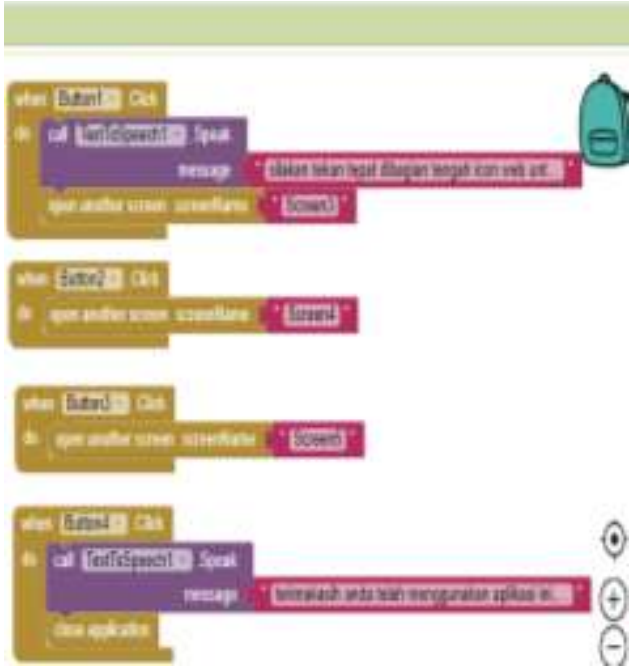

(b)

(a) Desain Menu Utama, (b) Blok Kode Disain Menu Utama

Pada tampilan menu utama, terdapat Beberapa Menu yang terdiri dari;

$>$ Button Menu MULAI yang digunakan untuk memulai pencarian Web yang sudah disediakan sesuai dengan kebutuhan pengguna di Politeknik Harapan Besama. Seperti pada tampilan Gambar 3 (a) diatas.

$>$ Button Menu BANTUAN yang berisi tentang deskripsi petunjuk penggunaan/Pengoperasian Aplikasi Portal Konten Web berbasis Android Mobile.

Button Menu TENTANG Menu Tentang mendeskripsikan tentang Tujuan dan fungsi dari Aplikasi Portal Konten Web Berbasis android Mobile.

> Button Menu KELUAR Pada Button Menu Keluar Fungsi dari Button ini digunakan untuk menutup dan Keluar dari Aplikasi.

4. Perancangan / Desin dan Blok kode untuk user Interface isi dari Menu utama 

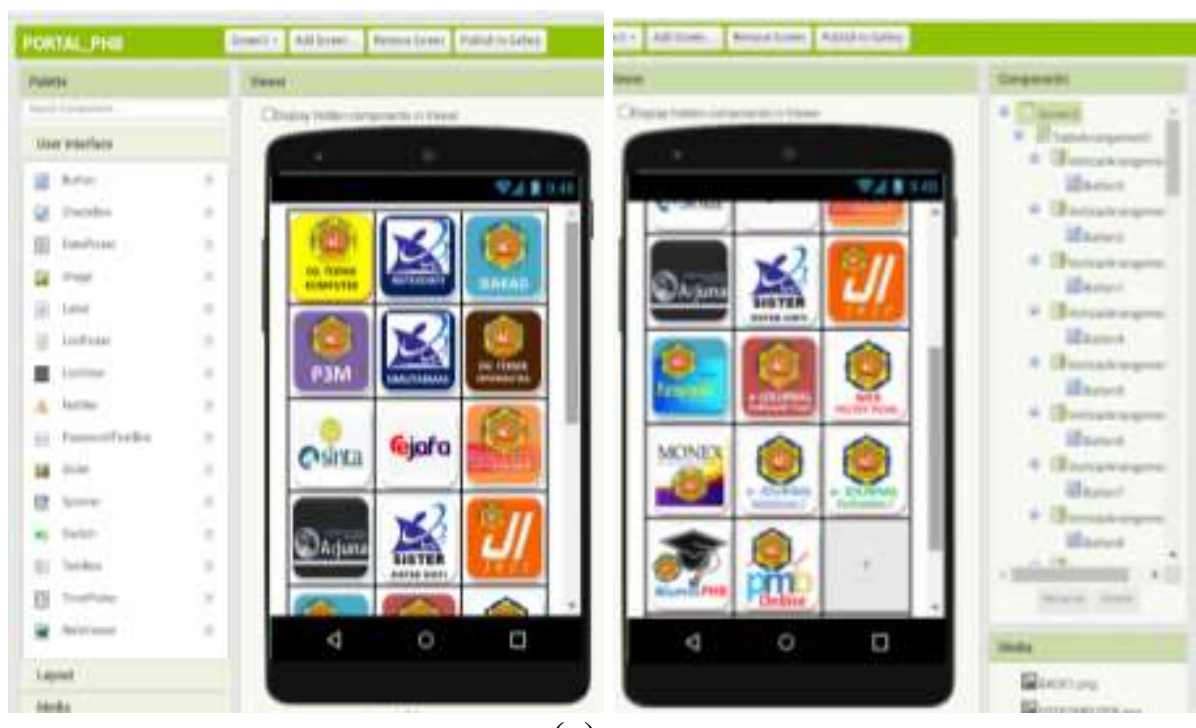

(a)
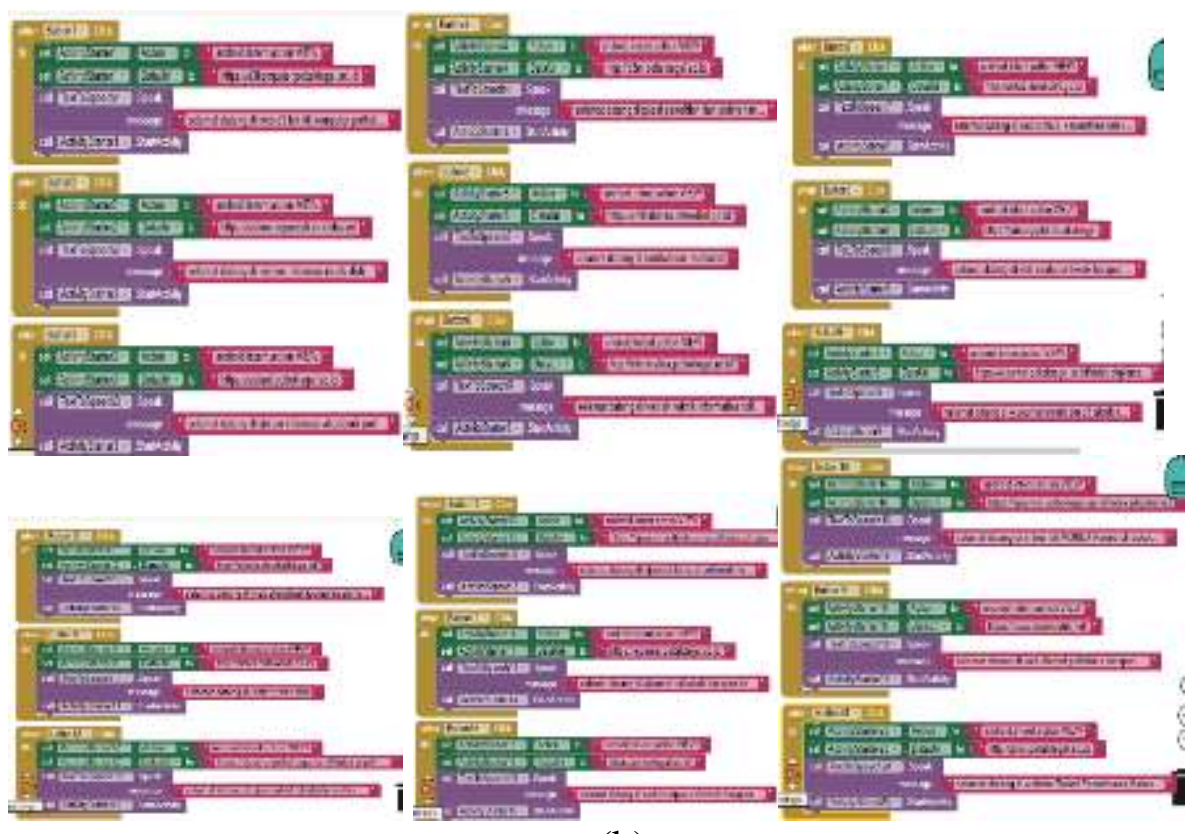

(b)

Gambar 4

(a) Desain Isi Menu Utama, (b) Blok Kode Isi Menu Utama

Dari setiap tampilan masing-masing Logo, pengguna hanya cukup klik/sentuh Logo dari Web yang akan dikunjungi dan akan langsung menuju ke alamat url nya dari Web yang akan dikunjungi tanpa harus menuliskan alamatnya. Sementara untuk logo yang masih kosong dengan tanda tanya (?) masih bisa di isi sesuai kebutuhan pengguna.

5. Perancangan/desain dan Blok kode untuk user Interface dari Menu Bantuan. 


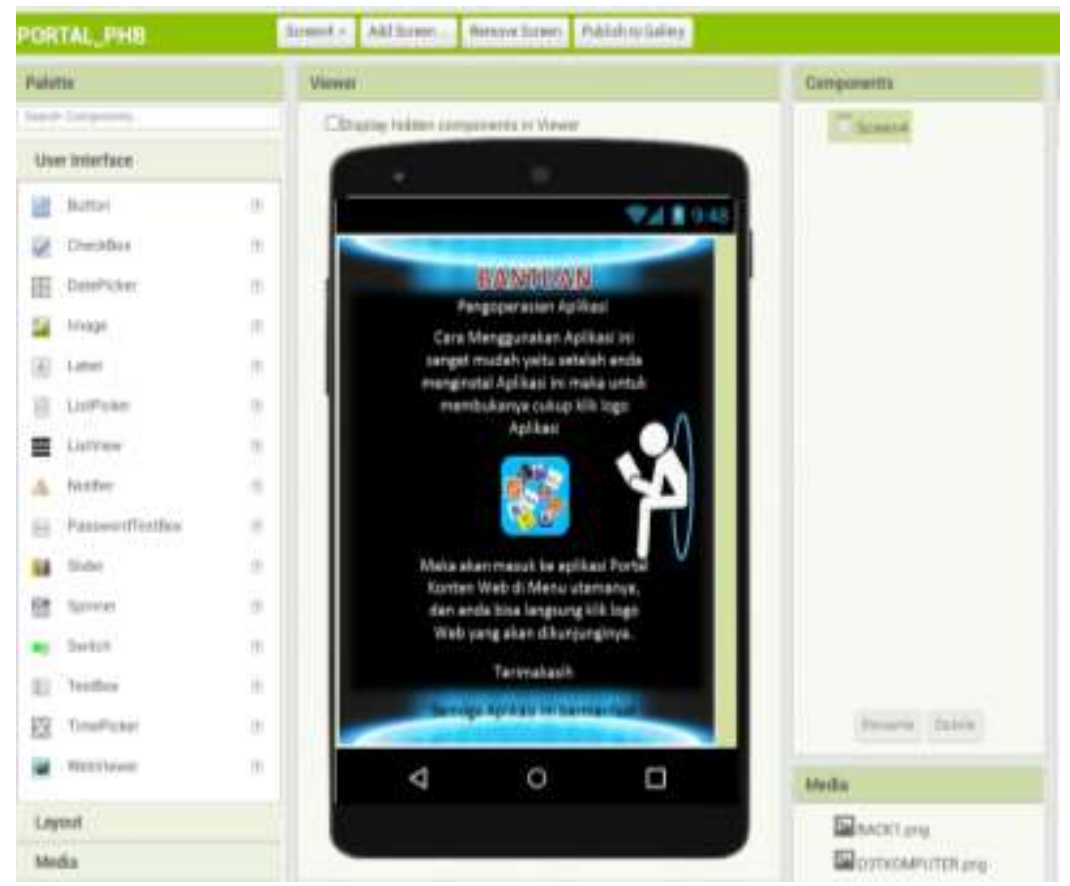

(a)

\section{when Button2 - Click \\ do open another screen screenName 1 "Screen4}

(b)

Gambar 5

\section{(A) Isi Dari Button Menu Tentang, (B) Blok Kode Untuk Button Bantuan}

Ketika pengguna ada kesulitan dalam menjalankan Aplikasi maka bisa langsung klik Button Menu BANTUAN yang berisi tentang deskripsi petunjuk penggunaan/Pengoperasian Aplikasi Portal Konten Web Berbsis Android seperti ditampilkan pada Gambar 5 (a).

6. Perancangan / Desain dan Blok kode untuk user Interface dari Menu Tentang.

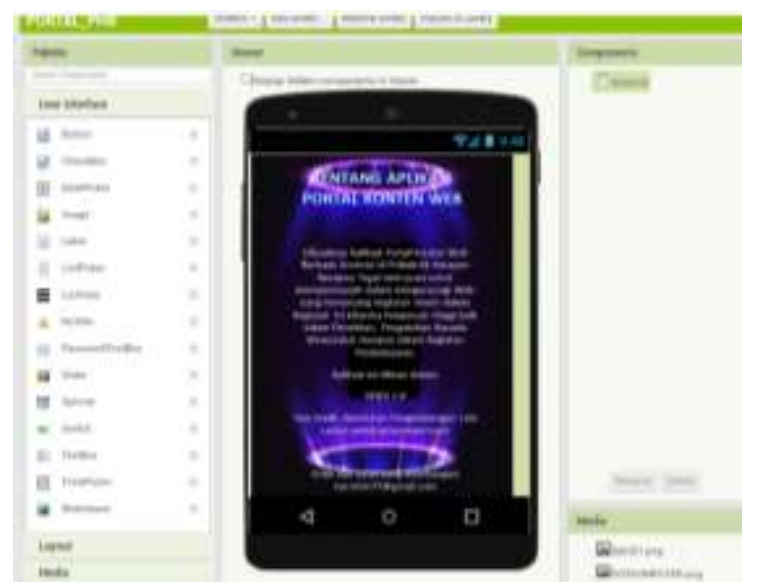

(a) 


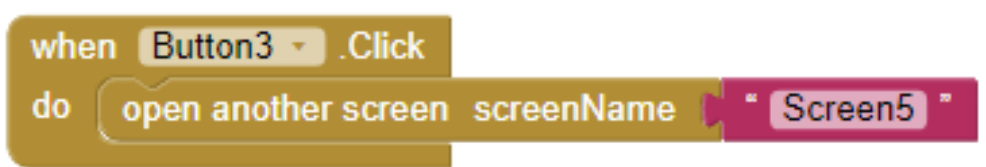

(b)

Gambar 6

\section{(A) Isi Dari Button Menu Tentang, (B) Blok Kode Untuk Button Tentang}

Menu Tentang mendeskripsikan tentang tujuan dan fungsi dari aplikasi portal konten web berbasis android, beserta versi dari aplikasi tersebut.

\section{B. Pengujian Hasil}

1. Hasil Pengujian dan pembahasan penelitian ini dari Planning/Perancangan sampai dengan testing / ujicoba Sistem dapat digambarkan pada Tabel. 1. proses impelementasi dari penggunaan Aplikasi Portal Konten Web Berbasis Android di Politeknik Harapan Bersama Tegal.

\section{Tabel 1}

Hasil Pengujian Program Aplikas Yang Dibuat

a) Tampilan Splash Screen

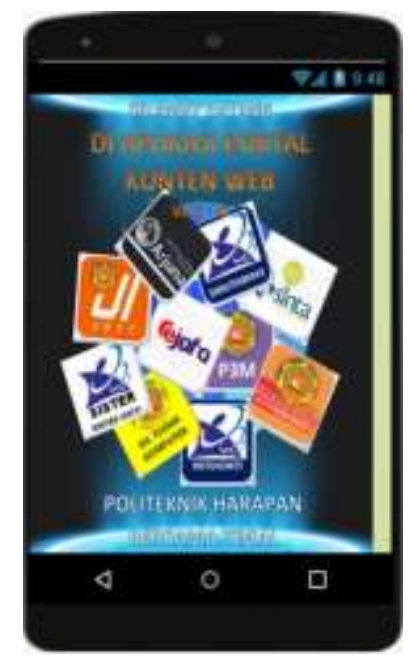

Gambar 1

Tampilan Splash Screen

Setelah anda menginstal aplikasi maka akan muncul logo aplikasi seperti ini

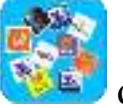
maka akan muncul Splash Screen selama 5 detik seperti pada Gambar 1 diatas.

\section{b) Tampilan Menu Utama}

Pada tampilan menu utama, terdapat 4 Menu yang terdiri dari ;

$>$ Button Menu MULAI yang digunakan untuk memulai pencarian Web yang sudah disediakan sesuai dengan kebutuhan pengguna di Politeknik Harapan Besama. Seperti pada tampilan Gambar 3 dibawah ini;
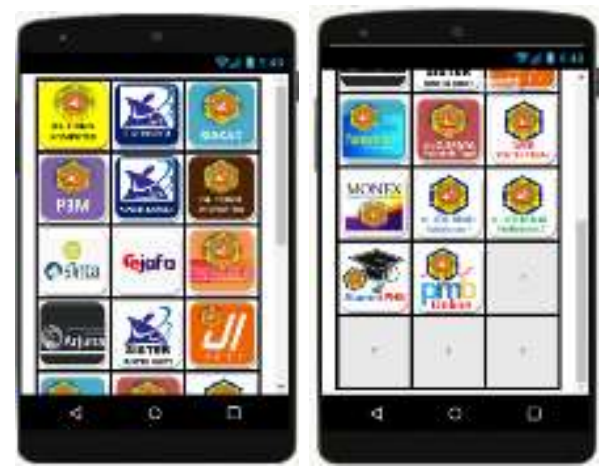

Gambar 3

\section{Tampilan Button Mulai}

Dari setiap tampilan masing-masing Logo, pengguna hanya cukup $\mathrm{Klik} / \mathrm{sentuh}$ Logo dari web yang akan dikunjungi dan akan langsung menuju ke alamat url nya dari web yang akan dikunjungi tanpa harus 


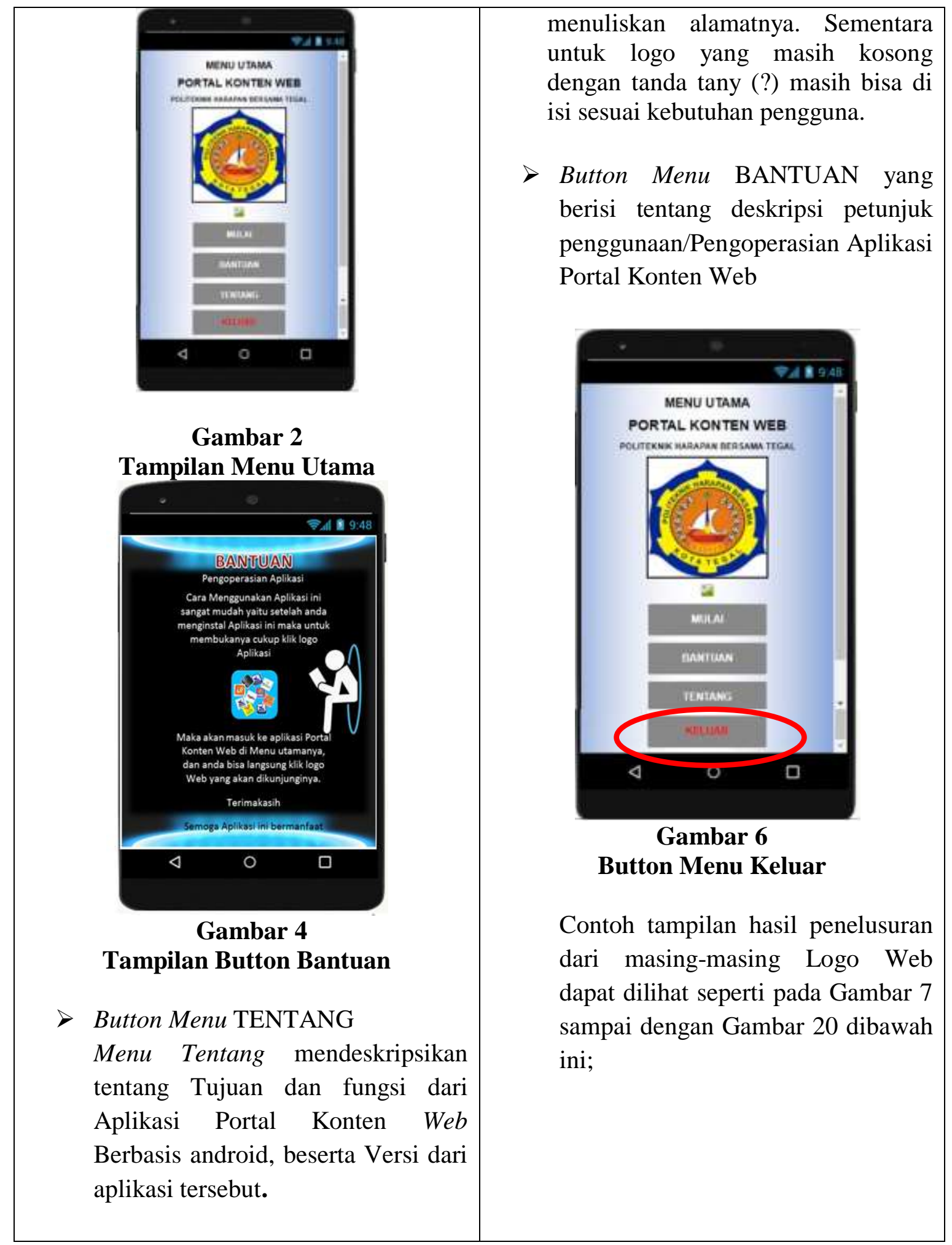




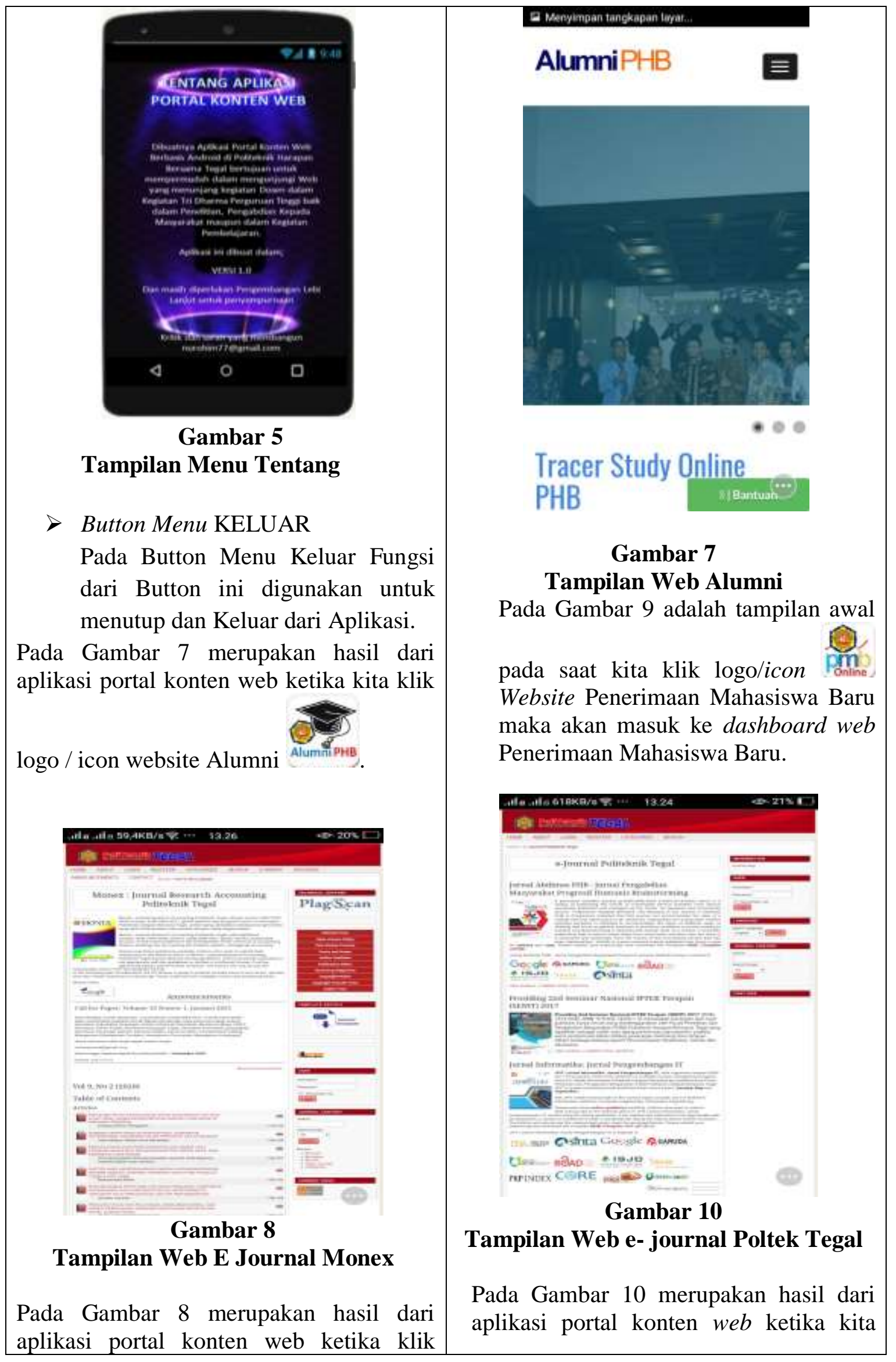




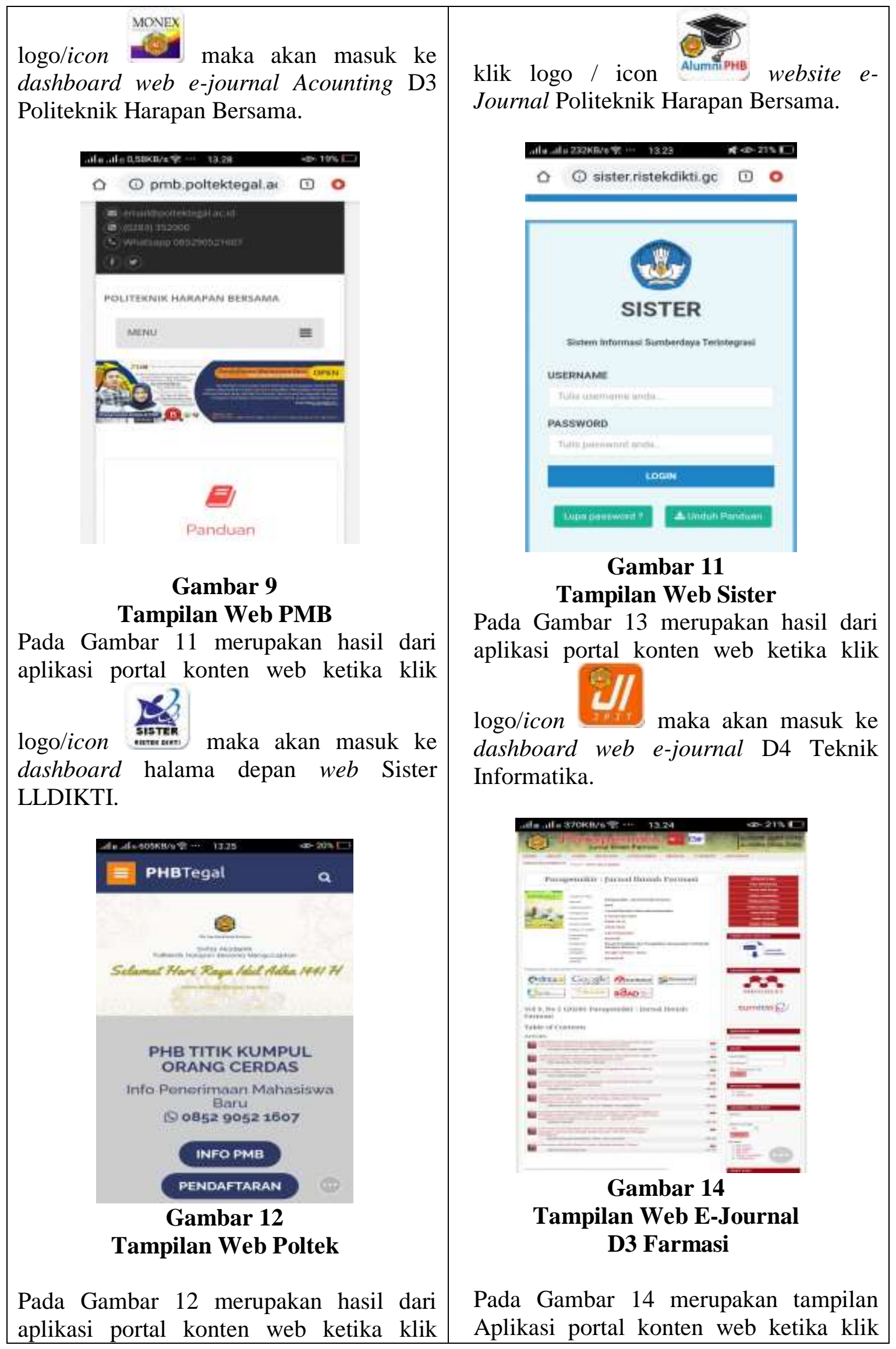




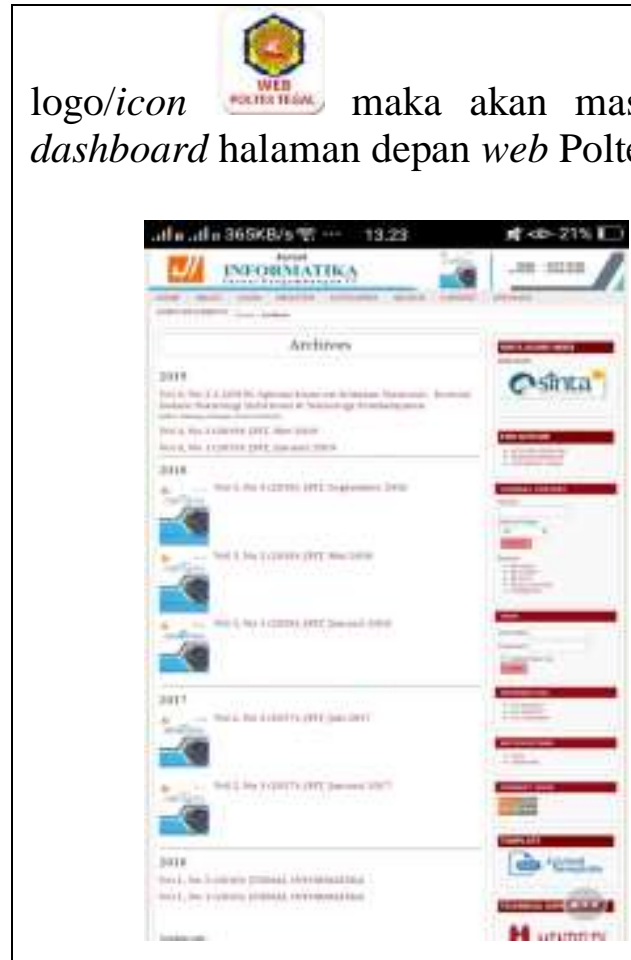

Gambar 13

Tampilan Web E-Journal JPIT D4 TI

Pada Gambar 15 merupakan tampilan Aplikasi portal konten web ketika klik

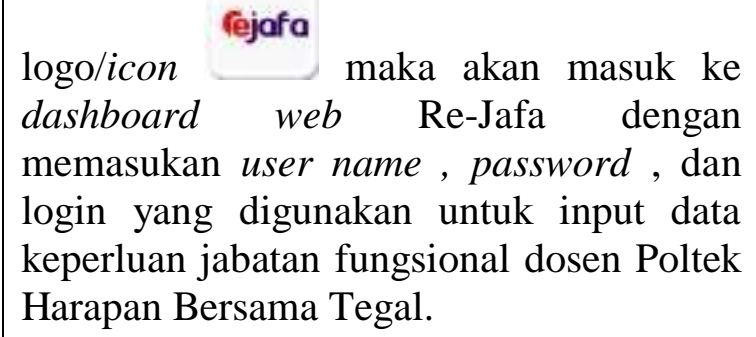

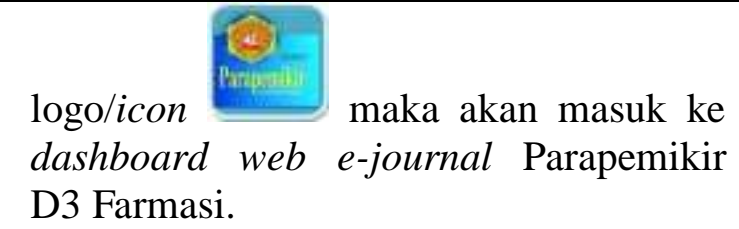
D3 Farmasi.
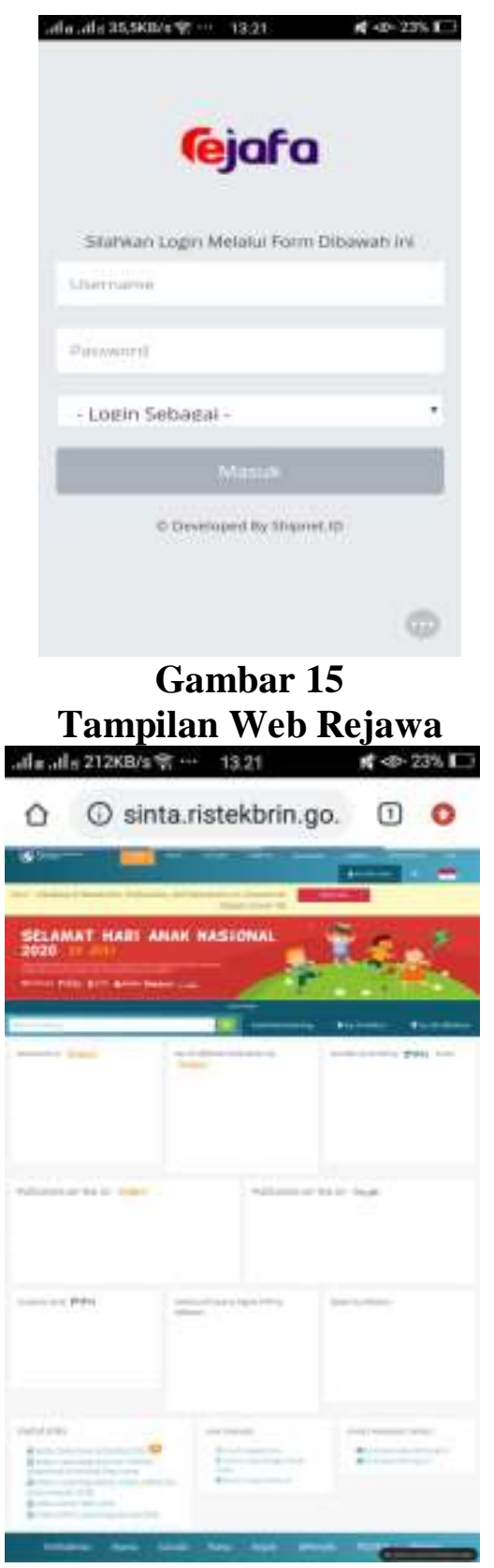

\section{Gambar 17}

Tampilan Web Sinta

Pada Gambar 16 merupakan tampilan Aplikasi portal konten web ketika klik

\section{Cinta}

maka akan masuk ke 


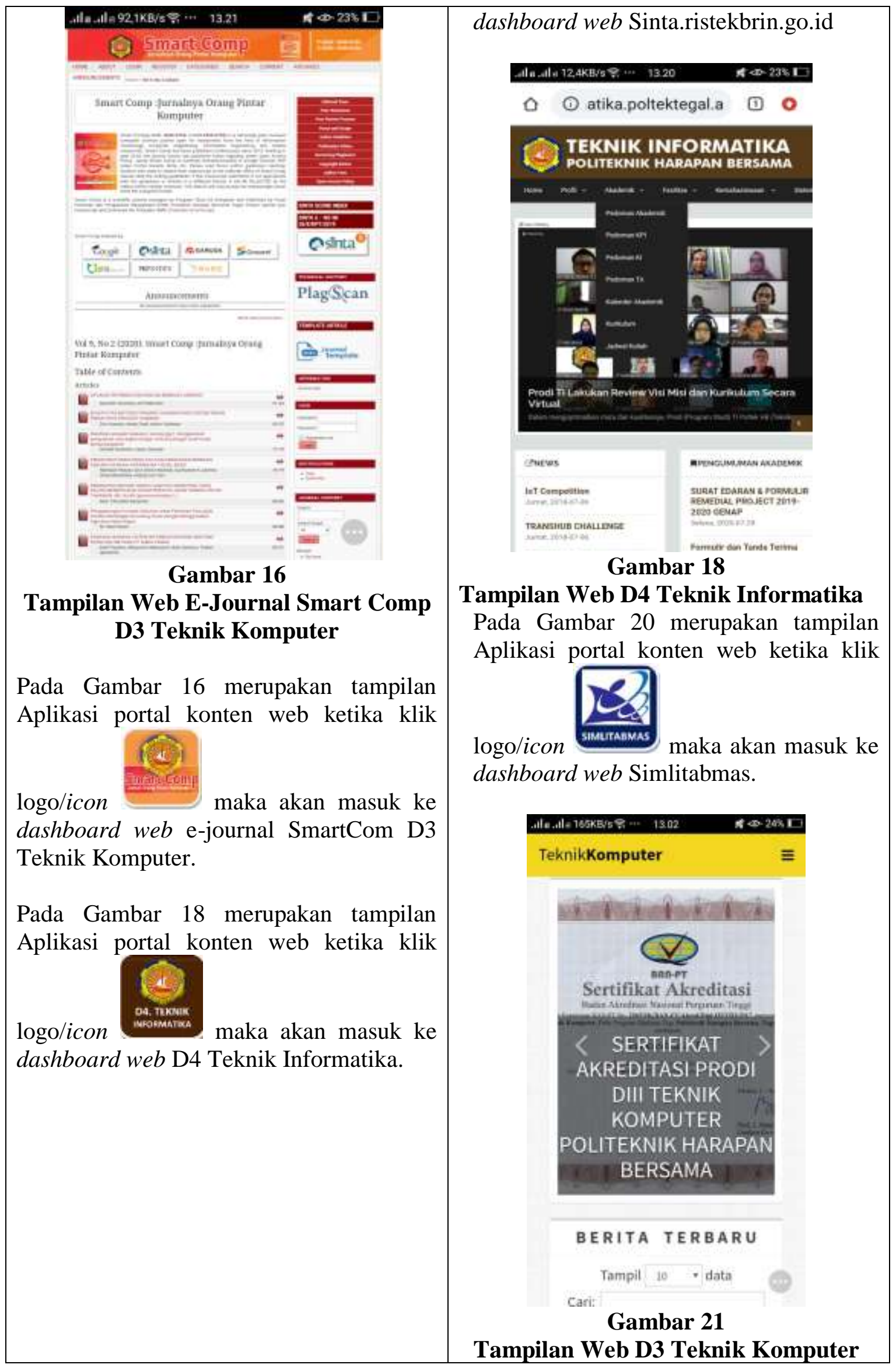




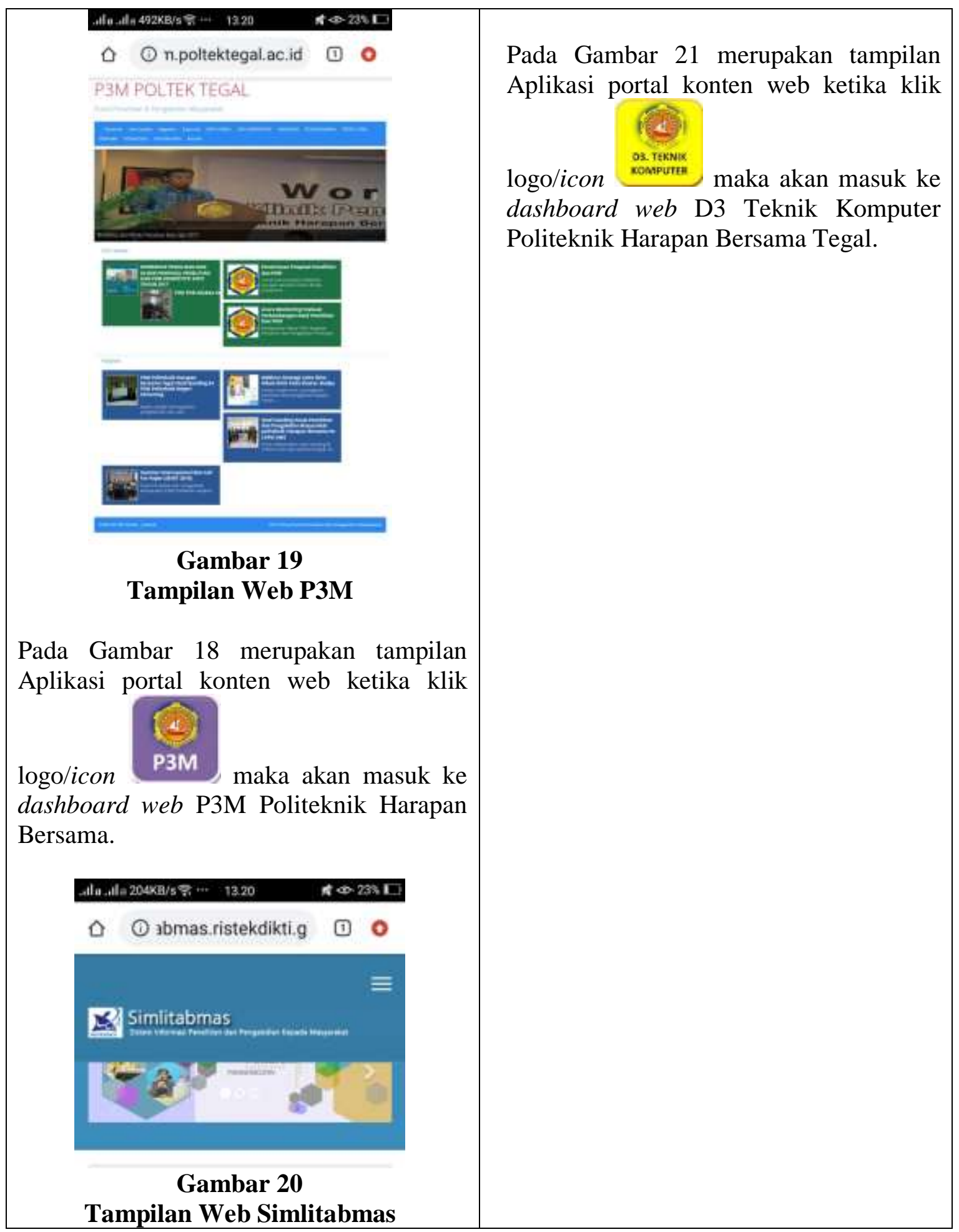

\section{Kesimpulan}

Berdasarkan analisis dan pembahasan sebelumnya maka simpulan dalam penelitian yang berjudul Aplikasi Portal Konten Web Berbasis Android Mobile untuk meningkatkan efektifitas dosen dalam Tridarma dengan pendekatan saintifik efektif, hal ini dapat dinyatakan sebagai berikut: 1). Hasil dari program Aplikasi berupa App Program dapat di instal diperangkat Smartphone dengan baik dan lancar. 2). Aplikasi ini 
dapat berjalan di operating system perangkat Mobile berbasis Android. 3). Aplikasi ini sangat efektif dan dapat membantu mempermundah dosen dalam mengunjungi situs web yang ada di aplikasi portal konten web hanya dengan satu kali sentuh saja. 


\section{BIBLIOGRAFI}

Antares. 2021. "Materi Dasar Tentang Membuat Aplikasi Android (Apk) Dan Menghubungkanya Ke Antares." 2021. https://antares.id/id/mitappinventor2.html.

Ardilas.com. 2020. "Fungsi-Dari-Tool-Toolbox-Menu-Layer-Adobe-Photoshop." 2020. http://www.ardilas.com/2016/02/fungsi-dari-tool-toolbox-menu-layer-adobephotoshop.html\#: :text=Fungsi utama dari Adobe Photoshop, yang bertipe raster atau bitmap.\&text=Fungsi Photoshop untuk membuat desain, Spanduk\%2C brosur\% $2 \mathrm{C}$ dan poster.

Dewi, Sarini Vita, and Edi Noviar Mayuska. 2019. "Perancangan Aplikasi Portal Informasi Mahasiswa Pada Universitas Ubudiyah Indonesia Berbasis Android." Journal of Informatics and Computer Science 5 (2): 117. https://doi.org/10.33143/jics.vol5.iss2.549. Google Scholar

Ernawati, Ernawati, Asahar Johar, and Sandi Setiawan. 2019. "Implementasi Metode String Matching Untuk Pencarian Berita Utama Pada Portal Berita Berbasis Android (Studi Kasus: Harian Rakyat Bengkulu)." Pseudocode 6 (1): 77-82. Google Scholar

Faizal, Mochammad, and Nurul Arifin Aristarini. 2020. "Perancangan Portal Berita Daring Magazinc! Sebagai Media Informasi Mahasiswa." Jurnal Bahasa Rupa 4 (1): 28-41. https://doi.org/10.31598/bahasarupa.v4i1.606. Google Scholar

Huda, Afrinaldi, Asrul, and Denny Kurniadi. 2015. "Aplikasi Mobile Portal Berita Ganto.or.Id Berbasis Android." Jurnal Vokasional Teknik Elektronika \& Informatika 3 (1): 1-10. Google Scholar

Julianto simatupang, Erica Septiani Hendarti. 2021. "Jurnal Intra Tech Ketenagakerjaan Berbasis Web Kata Kunci : Lowongan Pekerjaan, Sistem, Informasi Pendahuluan Jurnal Intra Tech Vol 5, No . 2 , Oktober 2021 Metode Penelitian Metode Waterfall” 5 (2). Google Scholar

Kurniawan, Yosef Koko, Yetli Oslan, and Harianto Kristanto. 2013. "Implementasi Rest - Api Untuk Portal Akademik Ukdw Berbasis Android." Jurnal EKSIS 6: 2940. Google Scholar

Lesomar, Fransiskus, Hans Wowor, and Virginia Tulenan. 2015. "Rancang Bangun Portal WEb Pariwisata Maluku Tenggara." Jurnal Teknik Informatika 6 (1): 2-7. Google Scholar

Mariko, Selli. 2020. "Perancangan Portal E-Learning Menggunakan Drupal Cms Sebagai Penunjang Perkuliahan Pada Masa Pandemic Covid-19." Edutic Scientific Journal of Informatics Education 6 (2). Google Scholar

Martias, Andi. 2018. “Analisa Kecukupan Penerapan Pengawasan Internal Dengan 
Metode System Development Life Cycle PT. XYZ.” Moneter 5 (2): 23-32. Google Scholar

Pote, J Y, and Y Rada. 2020. "Implementasi Portal News Citizen Journalism Dengan Konsep MVC Sebagai Media Promosi Konten Lokal Di Pulau Sumba.” Respati XV: 75-83. Google Scholar

Rahayu, Luci Kanti, Agustiena Merdekawati, and Wasis Zakaria. 2019. "Aplikasi Inventory Outlet Pada PT . Konimex Jakarta Berbasis Android" 3 (4): 19-27. Google Scholar

Ramadhan, Wahyudi Fajar, Wiwiek Nurkomala Dewi, and Chairun Nas. 2020. "Aplikasi Web Portal Manajemen Informatika Berbasis Website Dengan Menggunakan Framework Codeigniter Dan Mysql Pada Universitas Catur Insan Cendekia." Jurnal Digit 10 (2): 124. Google Scholar

Wihidayat, Endar Suprih, and Dwi Maryono. 2017. "Pengembangan Aplikasi Android Menggunakan Integrated Development Environment (Ide) App Inventor-2.” Jurnal Edutic 4 (1): 1-12. Google Scholar

\section{Copyright holder:}

Nurohim, Wildani eko nugroho (2022)

First publication right:

Syntax Literate: Jurnal Ilmiah Indonesia

This article is licensed under:

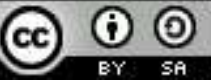

